\title{
The self-care behaviour association with quality of life among Chinese ethnic with heart failure in Malaysia
}

\author{
Perhubungan antara tingkah laku penjagaan diri dan kualiti hidup di antara etnik Cina \\ dengan kegagalan jantung di Malaysia
}

\section{Chong Yen Yee ${ }^{1 *}$, Nor Firdous Mohamed ${ }^{1}$, Nor Ashikin Md Sari ${ }^{2}$, Nur Amani Ahmad Tajuddin²}

\author{
${ }^{1}$ Faculty of Human Development, Sultan Idris Education University, Tanjong Malim, Perak, Malaysia \\ ${ }^{2}$ Faculty of Medicines, University Malaya, Kuala Lumpur, Malaysia \\ *e-mail: d072428@siswa.upsi.edu.my
}

Received: 06 June 2020; Accepted: 16 March 2021; Published: 17 March 2021

To cite this article (APA): Yen Yee, C., Mohamed, N. F., Md Sari, N. A., \& Ahmad Tajuddin, N. A. (2021). The self-care behaviour association with quality of life among Chinese ethnic with heart failure in Malaysia. EDUCATUM Journal of Social Sciences, 7(1), 77-82. https://doi.org/10.37134/ejoss.vol7.1.8.2021

To link to this article: https://doi.org/10.37134/ejoss.vol7.1.8.2021

\begin{abstract}
The aim of this study is to determine the association between self-care behaviour and quality of life among the Chinese ethnic with heart failure (HF) in Malaysia. A cross-sectional survey design was conducted with $80 \mathrm{HF}$ patients. The average age of participants was 61.39 years old $(\mathrm{M}=61.39, \mathrm{SD}=15.88)$. Chinese version of Selfcare Heart Failure Index version 6.2 and the World Health Organization Quality of life-BREF were utilized in this study. Pearson's correlation and t-test were tested to run the analysis. Current findings suggested that the construct of confident to conduct self-care is significantly correlated positively with quality of life $(\mathrm{r}=.41, \mathrm{p}<0.01)$. There is a significant difference in self-care management between genders $[\mathrm{t}(78)=-2.94, \mathrm{p}=.00]$ and illness comorbidities $[\mathrm{t}(78)=-2.07, \mathrm{p}=.04]$. Hence, it is suggested that element of confidence is one of the important factors to be considered in future self-care interventions. Through this study, researchers and health-care providers could deduce effective interventions and education considering genders and illness comorbidities in order to improve self-care behaviours and quality of life.
\end{abstract}

Keywords: Heart failure, Malaysia, Chinese ethnic, Quality of life, Self-care

\begin{abstract}
Abstrak
Tujuan kajian ini adalah untuk mengetahui perhubungan antara tingkah laku penjagaan diri dan kualiti hidup di antara etnik Cina kegagalan jantung di Malaysia. Kajian tinjauan keratan rentas dilaksanakan pada 80 pesakit kegagalan jantung. Umur rata-rata peserta adalah 61.39 tahun $(\mathrm{min}=61.39$, sisihan piawai $=15.88)$. Indeks Kegagalan Jantung Rawatan Penjagaan Diri versi 6.2 dan Kualiti Hidup Organisasi Kesihatan Sedunia-BREF versi Cina digunakan dalam kajian ini. Korelasi Pearson dan ujian-t adalah ujian untuk menjalankan analisis. Penemuan semasa menunjukkan bahawa keyakinan diri berkorelasi positif secara signifikan dengan kualiti hidup $(r=.41, p<0.01)$. Terdapat perbezaan yang signifikan dalam pengurusan penjagaan diri antara jantina [ $t(78)$ $=-2.94, p=.00]$ dan komorbiditi penyakit [t $(78)=-2.07, p=.04]$. Justeru, intervensi harus dilaksanakan untuk meningkatkan keyakinan diri agar kualiti hidup meningkat di kalangan etnik Cina pesakit kegagalan jantung dengan mempertimbangkan perbezaan jantina dan komorbiditi. Melalui kajian ini, penyelidik dan penjawat perubatan dapat menyimpulkan intervensi dan pendidikan yang berkesan dengan mempertimbangkan jantina dan komorbiditi penyakit untuk meningkatkan tingkah laku penjagaan diri dan kualiti hidup.
\end{abstract}

Kata kunci:Kegagalan jantung, Malaysia, Etnik Cina, Kualiti Hidup, Penjagaan Diri 


\section{INTRODUCTION}

Cardiovascular disease (CVD) is an epidemic and among the number one cause of mortality and morbidity which caused 17.9 million deaths per year according to World Health Organization (WHO) 2018. Besides that, the number of heart failure (HF) patients worldwide is increasing, with the condition affecting an estimated 26 million people globally. HF is defined as the end stage of heart disease. It is when the heart muscle is not able to efficiently pump sufficient blood and oxygen in order to meet the needs of the body. In accordance to that, rehabilitation measures need be tailored to the patients considering various sociocultural factors as a result to improve the quality of life (QOL) among the patients (Mohamed, Ghazali, Yaacob, Azan \& Maskon, 2018). Past research have suggested that HF patients have suffered from a bad quality of life (Napier, McNulty, Eton, Redfield, AbouEzzeddine \& Dunlay, 2018).

According to a press released by the Department of Statistics Malaysia in 2018, the percentage of deaths caused by Ischaemic heart diseases was $13.9 \%$ in 2017, which remains as the principal cause of death. Heart disease is the main cause of death for all major ethnic groups. Chinese ethnic recorded the second highest increase of 0.2 percentage point from 13.0 per cent (2016) to 13.2 per cent (2017).

Self-care behaviour is a decision-making process of an individual that stabilize physiologically, forming the perception towards the symptoms and behaviour to manage those symptoms (Sedlar, Lainscak, Mårtensson, Strömberg, Jaarsma, \& Farkas, 2017). In addition, quality of life is an individual's perception of their condition in life which influenced by the culture and value as per described by the World Health Organization (WHO). Self-care improves outcomes and quality of life among patients with heart failure. However, there is no study which have been conducted previously on this topic among Malaysian Chinese ethnics. Hence, this study is aimed to improve the quality of life among Chinese ethnic HF patients based on the ethnicity's unique sociocultural factors. Quality of life issues are also among the crucial topics to be studied in the area of health care.

Self-care is vital to the health outcomes in heart failure patients, especially health-related quality of life (HRQOL) (Kessing, Denollet, Widdershoven, \& Kupper, 2017). Cardiovascular disease effects both males and females, however, according to a research conducted by Mehta and Cowie (2006), the health issue of heart failure is lower in females than in males at all ages. Hence this suggest that gender plays a major role in the outcome of the disease. According to Vellone et al. (2015), 70\% of HF patients suffer from one or more other comorbidities.

The National Cardiovascular Disease Registry in Malaysia has found out that female patients had a higher in-hospital and 30-day mortality for heart disease compared to male patients. It is because the health care system seems to emphasize more on male patients as they appear to develop the disease at an earlier age compared to the female patients. In fact, the occurrence of cardiovascular disease in female patience rises swiftly after menopause. Hence such statistics suggest that treatment and intervention should focus on gender differences. Comorbidities that are common among heart failure patients are diabetes, chronic kidney disease and cancer. Among the comorbidities such as dyslipidaemia, diabetes mellitus and hypertension are common among Malaysian HF patients, 52\%. 67\% and 75\% respectively (Reyes, Ha, Firdaus, Mohd, Phrommintikul, Sim, Quynh, Chung, Yin \& Cowie, 2016). The current study examines the differences in self-care behaviour between genders and comorbidities because past studies have suggested that these variables might have a role in the self-care behaviour of the HF patients.

\section{LITERATURE REVIEW}

Reviewed articles and literatures showed that self-care behaviours have an influence on HRQOL. Auld, Mudd, Gelow, Hiatt \& Lee (2018) have conducted a study to determine the possibilities of HF self-care behaviours to moderate the relationships between physical and emotional HRQOL. The samples were 
202 HF patients with NYHA class III and IV. The relationships between the variables were determined by evaluating the interaction between self-care behaviours and physical HF symptoms on emotional HRQOL. The instruments used in this study was self-care of HF index maintenance and management scales, HF Somatic Perception Scale and emotional dimension of Minnesota Living with HF questionnaire. The result indicates that self-care maintenance moderated the relationship between physical and emotional HRQOL. In conclusion, HRQOL depends on the level of engagement in HF self-care behaviours.

\section{MATERIALS AND METHODS}

There are three objectives of the study which are:

a) To examine the association between self-care behaviour and quality of life among Chinese ethnic with HF in Malaysia.

b) To examine the difference in self-care behaviour between genders among Chinese ethnic with $\mathrm{HF}$ in Malaysia.

c) To examine the difference in self-care behaviour between comorbid and non-comorbid among Chinese ethnic with HF in Malaysia.

The variables in this study are self-care behaviour and quality of life where, self-care behaviour as independent variable and quality of life as dependent variable. Survey research and cross-sectional design was implemented to obtain data from respondents. A set of questionnaires that comprised of three instruments which were socio-demographic questionnaire, Chinese version of World Health Organization Quality of life-BREF (WHOQOL-BREF) questionnaire and Chinese version of Self-care Heart Failure Index version 6.2 (SCHFI-v6.2) questionnaire were used for data collection.

The main criteria in socio-demographic questionnaire was to obtain information on gender, age, marital status, education level, working status, days spent in hospital per year, co-morbidities and severity level of illness (ejection fraction percentage). The WHOQOL-BREF is an instrument to assess quality of life which is cross-culturally comparable (The WHOQOL Group, 1998). It is one of the commonly used generic self-report QOL questionnaires developed in diverse cultures (Xia, Li, Hau, Liu \& Lu, 2012). The SCHFI is an instrument to measure the three self-care behaviours which are self-care maintenance, self-care management and self-care confident.

The respondents for the current study were 80 Chinese ethnic heart failure outpatients from National Heart Institute (IJN) and University of Malaya Medical Centre (UMMC). The respondents were assessed by cardiologists for HF severity according to the criteria of reduced left ventricular function (ejection fraction of $<55 \%$ ) and symptoms of heart failure such as congestion in the lungs, shortness of breath and edema.

Descriptive and inferential statistics were utilized to analyse the collected data. Data was summarized using descriptive statistics such as frequency counts, means, and standard deviations. Null hypothesis testing was analysed to examine the association of self-care behaviour and quality of life. Correlation analysis was conducted by using Pearson's correlation, comparison analysis was conducted by using ttest. Permission to conduct research on human subjects was obtained by the ethics review board of IJN and UMMC prior to the recruitment of the participants. 


\section{RESULTS AND DISCUSSION}

Table 1.0: Correlation Analysis between Self-care and Quality of Life $(n=80)$

\begin{tabular}{lccccc}
\hline & $\begin{array}{l}\text { WHOQOL- } \\
\text { BREF }\end{array}$ & Physical & Psychological & $\begin{array}{l}\text { Social } \\
\text { Relationships }\end{array}$ & Environment \\
\hline $\begin{array}{l}\text { Self-care } \\
\begin{array}{l}\text { Maintenance } \\
\text { Self-care }\end{array}\end{array}$ & .05 & -.00 & .06 & .10 & .04 \\
$\begin{array}{l}\text { Management } \\
\begin{array}{l}\text { Self-care } \\
\text { Confident }\end{array}\end{array}$ & .08 & .02 & .13 & .04 & .07 \\
Correlation is significant at the 0.01 level (2-tailed). & $.37^{* *}$ & $.43^{* *}$ & .15 & $.41^{* *}$ \\
\hline
\end{tabular}

There is a significant positive correlation between self-care confidence and quality of life. Self-care confidence is significantly positively correlated with the domains of WHOQOL-BREF including physical, psychological and environment. Physical domain indicates the energy, sleep and mobility of the patients; psychological domain measures the feelings, thinking and bodily image whereas environment domain examines the security, financial resources and participation in leisure activity. When the self-care confidence among the HF patients increases, the quality of life increases as well. Hence, there is an association between self-care behaviour and quality of life among Chinese ethnic of HF patients in Malaysia population. Self-care confidence is the vital aspect for better prognosis and quality of life in HF patients (Riegel, Vaughan, Kuhn, Page \& Worrall-carter, 2010). Thus, improving self-care behaviour are able to improve quality of life.

However, self-care confidence is not correlated with the social relationships domain of WHOQOLBREF. The social relationships incorporated the personal relationships, social support as well as sexual activity. This could be due to the respondents scoring the lowest in social relationships domain when rating their quality of life. Female patients with the presence of social support has resulted in the lower self-care in female HF patients (Mei, Tian, Chai \& Fan, 2019). Besides that, the effect of social support of HF self-care did not reveal a significant relationship based on previous studies (Binu, Cheryl, Himmelfarb, Davidson \& Reiko, 2018).

Table 2.0: Independent t-test analysis of SCHFI-v6.2 between males $(n=48)$ and females $(n=32)$

\begin{tabular}{|c|c|c|c|c|}
\hline & \multicolumn{2}{|c|}{ Mean (Standard Deviation } & \multirow[b]{2}{*}{$t$-value } & \multirow[b]{2}{*}{$p$-value } \\
\hline & Male & Female & & \\
\hline Self-care & $12.77(3.21)$ & $13.75(2.92)$ & -1.39 & .17 \\
\hline Maintenance & & & & \\
\hline Self-care & $17.63(3.58)$ & $19.88(2.97)$ & -2.94 & $.00^{*}$ \\
\hline Management & & & & \\
\hline Self-care Confident & $20.17(3.93)$ & $20.25(4.07)$ & -.09 & .93 \\
\hline
\end{tabular}

There is a significant difference in self-care behaviour between males and females among Chinese ethnic of HF patients in Malaysia population. Self-care management is adequate in both genders with HF. However, the average self-care management of females is higher compared to males. Gender is categorised as one of the personal factors affecting HF self-care alongside with other personal factors such as age, employment status, marital status, family income and education (Binu, Cheryl, Himmelfarb, Davidson \& Reiko, 2018).

This current study shows that there are different factors affecting males and females' self-care behaviours. Female HF patients are able to recognize the symptoms and implement the treatments more efficiently as compared to male HF patients (Dellafiore, Arrigoni, Pittella \& Conte, 2018). Hence, 
interventions should be implemented for enhancing self-care management and strengthening the knowledge of heart failure in male HF patients.

Table 3.0: Independent t-test analysis of SCHFI-v6.2 between non-comorbid $(n=48)$ and comorbid $(n=32)$

\begin{tabular}{|c|c|c|c|c|}
\hline & \multicolumn{2}{|c|}{ Mean (Standard Deviation) } & \multirow[b]{2}{*}{$t$-value } & \multirow[b]{2}{*}{$p$-value } \\
\hline & $\begin{array}{c}\text { Non- } \\
\text { comorbid }\end{array}$ & Comorbid & & \\
\hline Self-care & $12.63(3.08)$ & $13.97(3.04)$ & -1.92 & .06 \\
\hline Maintenance & & & & \\
\hline Self-care & $17.88(3.67)$ & $19.50(3.07)$ & -2.07 & $.04 *$ \\
\hline Self-care Confident & $19.83(4.08)$ & $20.75(3.78)$ & -1.01 & .31 \\
\hline
\end{tabular}

There is a significant difference in self-care behaviour between comorbid and non-comorbid among Malaysian Chinese ethnic HF patients population. Self-care management was adequate in both noncomorbidity and patients with comorbidity/s. However, the average self-care management of participants with comorbidity/s is higher compared to non-comorbidity. As a result, the participants with comorbidity/s are able to recognize the symptoms and implement the treatments more efficiently compared to the non-comorbid patients.

Comorbidities is categorised as one of the risk factors affecting HF self-care. There was evidence on statistically significant positive association between comorbidity and self-care management. The higher the comorbidities, the higher the patient's self-care. This can be explained when individuals with higher comorbidities felt the need and have the motivation to better care for themselves due to increasing symptoms and decreasing functional capability (Binu, Cheryl, Himmelfarb, Davidson \& Reiko, 2018). Hence, education and intervention can be highlighted to non-comorbid patients prior to them developing comorbid illness. Therapeutic patient education interventions should focus on recognition and selfmonitory change in HF condition. Besides that, family-focused interventions are used to strengthen support from family and environmental restructuring (Barnason, White-williams, Rossi, Centeno, Crabbe, Lee, Wood, 2017).

\section{CONCLUSION}

In conclusion, Chinese ethnic with HF in Malaysia has better self-care confidence and satisfactory quality of life. However, interventions and education targeting self-care confidence is mandatory to maximise the self-care behaviour and quality of life. Health-care providers should deduce effective interventions and education with consideration on males and females, patients with comorbidity and without comorbidities in order to improve self-care behaviours and quality of life. A tailored patient intervention among Chinese ethnic with HF in Malaysia can be implemented in order to improve prognosis, reduce hospitalization and have better outcomes (Lainscak, Blue, Clark et al., 2011).

The limitation of this study was the selection of the sample which may not be an accurate representation of all Chinese ethnic with HF in Malaysia since this study only focused on patients from National Heart Institute (IJN) and University of Malaya Medical Centre (UMMC). Hence, future research can be conducted by including Chinese ethnic with HF from other health institutions in the data collection.

Last but not least, this study needs further explorations in this area from a wider sample size to execute more significant results to deduce a tailored patient intervention considering the sociocultural factors. Thus, it is recommended that such a study like this, to increase the number of participants and explore more factors related to self-care behaviour in the future research (Perveen, Hamzah, Khatyjah \& Morgul, 2018). 


\section{REFERENCES}

Barnason, S., White-williams, C., Rossi, L. P., Centeno, M., Crabbe, D. L., Lee, K. S., Wood, K. (2017). Evidence for Therapeutic Patient Education Interventions to Promote Cardiovascular Patient Self-Management. 123. https://doi.org/10.1161/HCQ.0000000000000025

Binu, D. X., Cheryl, D. X., Himmelfarb, D., Davidson, M., \& Reiko, D. X. (2018). Factors affecting heart failure self-care: An integrative review $\mathrm{PhD}$, Professor and Dean a. Heart \& Lung, 47(6), 539-545. https://doi.org/10.1016/j.hrtlng.2018.09.004

Dellafiore, F., Arrigoni, C., Pittella, F., \& Conte, G. (2018). Paradox of self-care gender differences among Italian patients with chronic heart failure: findings from a real-world cross-sectional study. 1-7. https://doi.org/10.1136/bmjopen-2018-021966

Heo, S., Moser, D. K., Lennie, T. A., Riegel, B., \& Chung, M. L. (2008). Gender differences in and factors related to self-care behaviors: A cross-sectional, correlational study of patients with heart failure. International Journal of Nursing Studies, 45(12), 1807-1815. https://doi.org/10.1016/j.ijnurstu.2008.05.008

Kessing, D., Denollet, J., Widdershoven, J., \& Kupper, N. (2017). Self-care and health-related quality of life in chronic heart failure: A longitudinal analysis. European Journal of Cardiovascular Nursing, 16(7), 605613. https://doi.org/10.1177/1474515117702021

Lainscak, M., Blue, L., Clark, A. L., Dahlström, U., Dickstein, K., Ekman, I., McDonagh, T., McMurray, J., Ryder, M., Stewart, S., Stromberg, A., Jaarsma, T. (2011). Self-care management of heart failure: Practical recommendations from the patient care committee of the heart failure association of the European society of cardiology. European Journal of Heart Failure, 13(2), 115-126. https://doi.org/10.1093/eurjhf/hfq219

Mehta, P. A., \& Cowie, M. R. (2006). Gender and heart failure: a population perspective. Suppl III, 92, 14-18. https://doi.org/10.1136/hrt.2005.070342

Mei, J., Tian, Y., Chai, X., \& Fan, X. (2019). International Journal of Nursing Sciences Gender differences in self-care maintenance and its associations among patients with chronic heart failure. International Journal of Nursing Sciences, 6(1), 58-64. https://doi.org/10.1016/j.ijnss.2018.11.008

Mohamed, Ghazali, Yaacob, Azan \& Maskon. (2018). Development and Validation of a Cross-Cultural Heart Failure-Specific Quality of Life Questionnaire. Sultan Qaboos University medical journal, 18(4), 494500. doi: 10.18295/squmj.2018.18.04.011

Mohd Isa, N. S., Omar, N., Mohd Fatzel, F. H., Mohd Ghazali, Z., \& Anas, N. (2021). The relationship between students' learning styles and academic performance: Final year accounting students. EDUCATUM Journal of Social Sciences, 7(1), 1-9. https://doi.org/10.37134/ejoss.vol7.1.1.2021

Perveen, A., Hamzah, H., Khatyjah, S., \& Morgul, E. (2018). Predicting Depressions with Child Abuse Potential among Career Parents in Melaka, Malaysia. EDUCATUM Journal of Social Sciences, 4(1), 10-13. Retrieved from https://ejournal.upsi.edu.my/index.php/EJOSS/article/view/536

Reyes, E. B., Ha, J., Firdaus, I., Mohd, A., Phrommintikul, A., Sim, D., Quynh, N. V., Chung, W. S., Yin, W. \& Cowie, M. (2016). Heart failure across Asia: Same healthcare burden but differences in organization of care. International Journal of Cardiology, 223, 163-167. https://doi.org/10.1016/j.ijcard.2016.07.256

Riegel, B., Vaughan, V., Kuhn, L., Page, K., \& Worrall-carter, L. (2010). International Journal of Nursing Studies Gender-specific barriers and facilitators to heart failure self-care: A mixed methods study. International Journal of Nursing Studies, 47(7), 888-895. https://doi.org/10.1016/j.ijnurstu.2009.12.011

Xia, P., Li, N., Hau, K.-T., Liu, C., \& Lu, Y. (2012). Quality of life of Chinese urban community residents: a psychometric study of the mainland Chinese version of the WHOQOL-BREF. BMC Medical Research Methodology, 12(1), 37. https://doi.org/10.1186/1471-2288-12-37

Napier, R, McNulty, S. E., Eton, D. T. Redfield, M. M., AbouEzzeddine, O., \& Dunlay, S. M. (2018). Comparing Measures to Assess Health-Related Quality of Life in Heart Failure with Preserved Ejection Fraction. JACC: Heart Failure, 6(7), 552-560. https://doi.org/10.1016/j.jchf.2018.02.006

Sedlar, N., Lainscak, M., Mårtensson, J., Strömberg, A., Jaarsma, T. \& Farkas, J. (2017). Factors related to selfcare behaviours in heart failure: A systematic review of European Heart Failure Self-Care Behaviour Scale studies. https://doi.org/10.1177/1474515117691644 